\title{
Students' Variables Predicting Timely Graduation at a Community College
}

\author{
Val Margarit \\ Nova Southeastern University \\ Jeff Kennedy \\ Palm Beach Atlantic University
}

Community colleges play a fundamental role in providing access to a college education for students from diverse backgrounds. According to 2006 data, only 28.0\% of first-time, full-time, degree-seeking community college students graduate with degrees within 3 years. Fewer than $45.0 \%$ of students who enter community college with a goal of achieving degrees or certificates are able to graduate within 6 years and $52.0 \%$ of first-time, full-time college students in public community colleges return for their 2 nd year. Moreover, only $8.5 \%$ of the state's population aged 25 and older had earned 2-year degrees. The purpose of this study is to explore the relationship between students' background, financial, academic, and students' timely graduation from a community college campus in central Florida.

The survey instrument was a questionnaire developed using Tinto's (1995) student integration model as the conceptual framework. The survey items were designed to capture background, financial, academic variables. The questionnaire was presented on-line and hosted by SurveyMonkey.com.

\section{INTRODUCTION}

Student graduation rates are one of the most critical issues facing community colleges today (Bailey \& Alfonso, 2005; Craig \& Ward, 2007; Derby, 2006). Community colleges play a fundamental role in providing access to a college education for a wide variety of students from diverse backgrounds (Bailey et al., 2004). However, graduation rates show that access alone is not enough. The American College Testing (ACT, 2006), found that $28 \%$ of the first-time, full-time, degree-seeking community college students graduate with degrees or certificates within 3 years, which is considered full time. Likewise, approximately $45 \%$ of them who plan to earn degrees or certificates do so 6 years later, and only $52 \%$ of students return for their 2nd year (ACT, 2006). Graduation rates are even lower for Hispanic students than any other ethnic group. In 2007, the National Center for Education Statistics (NCES; as cited in Aud, Fox, \& KewalRamany, 2010) stated that Hispanic students age 25 to 29 years have the lowest percentage of bachelor's degrees than any other ethnic group as shown by the following percentages: $11 \%$ Hispanics, $33 \%$ Whites, $17 \%$ African Americans, 62\% Asians, 13\% Native Hawaiian and Pacific Islanders, and 12\% American Indians and Alaska Natives. Likewise, as of 2008, Hispanic students held the lowest percentage of associate degrees than any other ethnic group as shown by the following percentages: $18 \%$ Hispanics, 
40\% Whites, 26\% African Americans, 56\% Asians and Pacific Islanders, and 25\% American Indians and Alaska Natives (Aud et al., 2010).

\section{Statement of the Problem}

For many students, community colleges seem to be the only route to achieving a higher education. Community colleges offer an open-door policy, which means that any student with a high school degree can seek a higher education degree. Often, the majority of the students enrolled at a community college are academically, economically, and socially disadvantaged (Bailey \& Alfonso, 2005; Cohen \& Brawer, 2009). For example, $30 \%$ of community college students are Black or Hispanic as compared to $20 \%$ of students at 4-year institutions (Horn \& Nevill, 2006). Moreover, 25\% of community college students come from low-income families compared to $20 \%$ of 4 -year college students (Horn \& Nevill, 2006). Additionally, many 1st-year community college students need at least one remedial course and take a longer time to complete the course than their peers (NCES, 2004).

Student persistence to graduation continues to remain a challenge for many community college leaders in the state of Florida because many students who start their college careers at community colleges never complete their degrees or certificates (Complete College America, 2011). Data from the 2005 to 2009 American Community Survey (as cited in the U.S. Census Bureau, 2009) showed little increase in the state of Florida's educational attainment rankings and almost no increase for Hispanic and African American students. According to the data, only $16.3 \%$ of the state's population aged 25 years or older had earned bachelor's degrees and 8.5\% had earned associate degrees (U.S. Census Bureau, 2009). Moreover, $14.1 \%$ of Hispanic students and $10.0 \%$ of African American students graduated with associate degrees within 3 years (NCES, 2004). These statistics demonstrate an urgent need for the Florida community college leaders to engage in meaningful analyses of the factors that impede college students' persistence to graduation.

The focus of this study was a central Florida college that was established in 1967 as a comprehensive, 2-year, public institution and, as of 2011, evolved into a 4-year institution of higher learning. The college is accredited by the Southern Association of Colleges and Schools to award associate and bachelor's degrees. Located in the central part of Florida, its programs and certificates serve the growing, diverse population of the area. Although the college offers a variety of degrees and has an overall retention rate of $68.0 \%$, students' graduation rates could be higher; only $39.0 \%$ of students graduate within 3 years, and only $12.0 \%$ of students graduate within 2 years. Among the graduates, $44.5 \%$ are Whites, $28.9 \%$ are African Americans, 49.3\% are Asians, 38.8\% are Hispanics, and 10\% are American Indians (Valencia College, 2012).

The problem examined in this study was to explore the factors that hindered student persistence and timely graduation from the community college. The lack of data precluded fully informed decision making regarding the effectiveness of strategies for addressing persistence and graduation rate and in identifying appropriate modifications to those strategies. Information from this study could assist college leaders in reassessing their current persistence to graduation strategies to reflect all students' needs.

\section{Background and Justification}

The community college has an open-admissions policy, which helps to enroll a wide variety of traditional and nontraditional students, first-generation students, and full-time and part-time students as well as returning students. The institution experiences increased student enrollment rates as well as retention rates; however, the graduation rate remains low.

The college's retention rate for the first-time, full-time, degree-seeking students from 2005 to 2009 was $65.6 \%$ (Valencia College, 2012). The above data indicated that a good percentage of students at the college needed help identifying the factors that would enable them to persist in college and graduate on time. Understanding the factors that influence student persistence in college could aid college administrators and other organizations of the college to develop and implement strategies for all students to persist and graduate on time. 


\section{Deficiencies in the Evidence}

Research on student persistence and graduation at community college institutions is limited because most of the research has been done at 4-year institutions (Scoggin \& Styron, 2006). The Florida Department of Education (as cited in Cooper, 2010) reported that over $43 \%$ of all undergraduates are enrolled in a community college; however, many of them do not graduate.

To understand and improve graduation rates, administrators and faculty must study and analyze the needs of students at their particular institutions. The literature on student persistence and graduation suggests that there is a need to explore, assess, and examine the barriers that prevent community college students from graduating on time.

\section{Audience}

The issue of students' timely graduation could benefit various stakeholders. This includes students participating in the study; faculty who will be able to study, assess, and adopt new strategies based on the study's results; college administrators who will be able to reform their retention programs and incorporate new strategies that will accommodate the student population likely to drop out; policy makers who will be able to use the research results to create new policies or reform existing ones; and future students who will be able to make decisions regarding whether to attend or not attend this community college based on programs that serve their needs.

\section{Definition of Terms}

The following terms are defined for the purpose of this study.

\section{Academic Integration Variables}

According to Tinto's (1995) student integration model, academic integration variables represent interaction between the student and the college that facilitate student integration into the college. This includes faculty-student interactions; classroom experiences; and diverse, student extracurricular activities available to students (Strauss \& Volkwein, 2004).

\section{Academic Variables}

These include personal study skills, class schedule, attendance, academic services, counseling services, motivation, and cognitive and affective skills.

\section{Environmental Factors}

These include financial status, family support, responsibilities, child care, employment schedule, and transportation.

\section{Full-time Students}

These are students who are enrolled in more than two courses within one quarter or semester at a postsecondary educational institution (Aslanian, 2001).

\section{Retention}

This refers to the process of retaining students within a specific program or educational institution until they complete the requirements needed for graduation.

\section{Student Success}

This refers to course completion and persistence of students to the 2nd year (Upcraft, Gardner, \& Barefoot, 2005). 
Self-efficacy

This refers to a person's belief about his or her capabilities to perform in specific circumstances in order to attain specific goals (Pintrich \& Schunk, 2002). Self-efficacy relates to one's expectations that will influence the choice, level of persistence, and ability to overcome obstacles and aversive experiences.

\section{Purpose of Study}

The purpose of this study is to explore the relationship between background, financial, and academic variables and students' timely graduation from a community college campus in central Florida. Educational attainment and college completion are imperative for students and for the future of the U.S. economy as well as for U.S. democracy. The main goal of community colleges is to serve the social and cultural needs of the communities of which they are part (Grubb, 2001) and to prepare students for the workforce (Giegerich, 2006). Therefore, it is imperative that community colleges find a way to help students develop skills and credentials they need for the 21-century global economy. For example, in the state of Florida, by 2020, 63\% of jobs will require college degrees; however, currently, only $32 \%$ of Florida adults have associate degrees or higher (ACT, 2006). To this end, the college under study must engage in new ways of thinking about graduating more students on time and not just retaining them.

\section{LITERATURE REVIEW}

This literature review examines the major factors that contribute to the high attrition rate of community college students as well as a number of strategies that might be adopted to reduce attrition. This review examines Tinto's $(1975,1997)$ model of student integration, Astin's (1993) model of integration, and Nora's (1990) model of student integration to develop a framework for the consideration of factors most contributing to attrition in community college students.

These models argue that retention is the outcome of a combination or synergy between academic and social belonging, academic and social, demographic or background student characteristics are addressed in this review.

The review closes with strategies that have been developed by institutions to help community college students navigate the phases of community college attendance. These strategies include mentoring, advising during induction, and transfer and the creation of communities of learning to reinforce Tinto's (as cited in Escobedo, 2007; Gonzalez, 2011b; Mackay, 2009; Smith, 2010; Stimpfel, 2008; Veenstra, 2009; Woolsey \& Shepler, 2007) belief in the interaction of academic and social dimensions of college life as leading to retention.

\section{Limitations of Graduation Rate as a Measure of Success}

Although graduation rate, the measure of retention, has been the focus of a great deal of research for improving community college retention rates recently, another line of research argues that graduation rates themselves tell only part of the story of what community colleges do. Sbrega (2012) noted that "anyone who fixates on graduation rates has little understanding not only of the rich mission and value of our community colleges, but also how deeply flawed and inadequate those rates are as a principle assessment tool for the performance of community colleges" (p. 1) . Furthermore, Sbrega argued that, although a $15 \%$ graduation rate is very low, $85 \%$ of community college students should not be included in the graduation rate database because they do not take a full load of courses and have no intention of graduating.

\section{Factors Contributing to Low Graduation Rates at Community Colleges}

Research on college-level attrition is grounded in some well-established models (Astin, 1993; DeilAmen, 2002; Mannan, 2007; Tinto, 1985, 1987, 1995, 1997). Deil-Amen (2011) argued that Tinto's $(1985,1987,1995,1997)$ model of student integration as well as Astin's (1993) theory of integration and Pascarella's model was primarily constructed to explain dropout behavior among 4-year college students 
and address the problems experienced by traditional college students, whereas it has not been applied to community colleges and nontraditional students.

\section{Student Background Factors}

Although research on college retention traditionally focused on academic predictors such as the Scholastic Assessment Test (SAT) and the American College Test (ACT) scores, grade point averages (GPAs), and other measures and showed that high school GPAs and standardized test scores were the strongest predictors of college GPAs, it is also true that prediction of success based strictly on academic values had only modest success (Bahr, 2008b; Breier, 2010; Chapa \& Schink, 2006; Crisp \& Nora, 2010; Doyle, 2006; Kurlaender, 2006; Lundberg, 2010; Malcom, 2010; Martinez \& Fernandez, 2004; O'Connor, 2009; Perrakis, 2008). As a result, many researchers have begun to refocus on noncognitive factors that may reinforce or deter from purely academic factors as a measure of prediction for college success.

\section{Ethnicity}

Martinez and Fernandez (2004) noted that $70 \%$ of all students in higher education are enrolled at community colleges, but, although minority students represent $21 \%$ of students in higher education, they represent $60 \%$ of students at community colleges. This means that minority students are overrepresented at community colleges. Reasons for this overrepresentation include low tuition, proximity to home, the availability of evening courses, remedial education, open admissions, and flexible schedules. Among Latinos enrolled in higher education, $60 \%$ are enrolled in community colleges. Some $50 \%$ to $87 \%$ of Latinos in community colleges aspire to bachelor's degrees, indicating a desire and motivation to succeed in college life. However, at the same time, research pointed to "the abysmally low percentage of Latino transfer rates to 4-year institutions" (Martinez \& Fernandez, 2004, p. 53).

One reason for this research finding is that Latinos are more likely to drop out of community colleges with attrition rates as high as $80 \%$ in one study cited by Martinez and Fernandez (2004). Half of Latino students never complete postsecondary degrees. In examining, why the transfer rate from community colleges is so low with no more than $15 \%$ of all students transferring, the authors indicated that the onset of a more vocational purpose in community colleges may be a factor. They noted that this transition relegated community college to the bottom of the hierarchy of higher education. This may cause Latino students a specific problem as they enter community colleges with espoused goals to transfer to 4-year colleges, but, then, the college support services focus on only vocational programs, thereby, "shortchanging the type of curriculum and student services needed to successfully transfer to senior institutions" (Martinez \& Fernandez, 2004, p. 54). In spite of their ambitions, if Latino students are not encouraged and mentored to transfer, many of them may not do so. As a result, students do not have the information or have not accumulated the credits needed to transfer, and they flounder. Low expectations and lack of articulation of pathways compound the problem. If, moreover, the administration leadership does not hold it as a matter of shared responsibility that the students will transfer, without this institutional level support, the odds of transfer greatly decrease.

\section{Financial Issues}

Tinto (1997) was noted for creating a longitudinal model of student dropout focused on the concept of integration that has become typical in the graduation rate and retention research. Tinto (as quoted in Breier, 2010) pointed out that individual departure from institutions can be viewed as arising out of a longitudinal process of interactions between individual with given attributes, skills, financial resources, prior educational experiences and dispositions (intentions and commitments) and other members of the academic and social systems of the institution. (p. 658)

This systemic view of attrition views dropout as occurring because of factors in the academic and social or personal integration areas. Although Tinto's (1997) model formed the basis of much attrition research over the past generation, Breier (2010) pointed out that the model has been criticized for its emphasis on the individual and downplaying other external factors linked to larger social, political, or 
economic forces. Breier also noted that largely Tinto assumed financial ability in most students and declared that financial considerations were of secondary importance to the decisions most students made.

Breier (2010) noted that, in Tinto's model, financial considerations are most relevant to decision making at the point when the student is applying to college and deciding whether to attend full time or part time. Later on in college life, Tinto (1997) believed that financial reasons often masked other true reasons for student withdrawal such as dissatisfaction with the institution. "Their citing financial reasons for leaving is simply another way of stating their view that the benefits of continued attendance do not outweigh the costs of doing so" (Breier, 2010, p. 660). Critics of this viewpoint, however, have found that student and parent perceptions of the ability to pay are important for attendance and for integration.

Financial pressure can also shape the college experience of students in positive and negative ways. Breier (2010) explored the degree to which financial considerations impact college completion in a population of low-socioeconomic students in South Africa. Many of the students experienced poverty and even food insecurity, meaning that financial considerations were important. Study results reflected that more leavers still relied on their family for finances than graduates, more of whom had part-time jobs. The leavers also had poorer results in the graduation tests in high school. Leavers were also brought up in a way that placed less emphasis on being motivated and focused. A cultural fit problem with the institution was also stated as a reason for dropping out as was HIV and AIDS.

Breier (2010) found that financial reasons not only loomed large as a reason for dropping out but also that, contrary to Tinto (1997) who argued that finances only played a part in attendance decisions, financial strains or pressure points arose at several points during the year to precipitate dropping out due to financial pressures. Although sudden demands can lead to departure, Breier also found that work-study programs can help students at these points. Thus, finances play a major role in not only a lowsocioeconomic student's decision to attend college but also can also lead to premature departure after registration "either because of unexpected financial demands or because the student underestimated the full cost of higher education" (Breier, 2010, p. 670). Social capital and personal habits may, in some cases, also offset the post registration pressures.

Chan, Chau, and Chan (2012) added still another dimension to the financial issues linked to student success based on the idea of social capital or the degree to which student financial management knowledge and skills contribute to their student debt and money problems. Chan et al. applied Kidwell and Turrisi's (2004) model on the financial management skills of Hong Kong college students. This model of money management links student debt to student financial management skill and has been used by colleges to screen college students' applications for financial aid. The model is based on the theory of planned behavior and the theory of social behavior, an extension of the theory of reasoned action, both of which found that a person's behavior can be predicted by behavioral intention, depending on attitude and subjective norm. Perceived behavior control has also been added to this model. In financial matters, not only student beliefs about money but also past behavior and habit as they intersect with social pressure account for current financial habits. Chan et al. found that $8.9 \%$ of respondents had financial problems, $30.0 \%$ with regard to funding extracurricular activities, and $20.5 \%$ reporting that financial concerns influenced their academic work. As a result, 35.8\% of students had part-time jobs although $45.5 \%$ of students were supported by their parents.

With regard to student beliefs and attitudes, Chan et al. (2012) confirmed that the likelihood of students engaging in healthy financial management practices is linked to their attitudes about debt and other financial control issues. Thus, in addition to financial problems, if students have not learned responsible financial behavior, that, too, could negatively impact their time in community colleges.

\section{Nontraditional Students}

Social or personal factors also account for the fact that community colleges are more likely to host not only traditional college-age students but also a greater number of older students who have not attended college, defined as being over the age of 25 years (Crisp \& Nora, 2010). A student who is over 25 years is classified in the literature as a nontraditional college student. For these older students, the fact that college is being inserted into a life that has previously taken other directions may or may not compromise their 
graduation rates. Factors utilized to determine the likelihood of graduation in traditional-aged college students in community colleges may not apply to older students (Breier, 2010).

The presence of older students in community colleges may skew graduation rates as well as retention policy in community colleges. One study indicated that $35 \%$ of students in community colleges were over the age of 25 years and had never previously attended college (Calcagno, Crosta, Bailey, \& Jenkins, 2007). These older students are more likely to be married, caring for children, and less likely to engage with traditional-aged college students on campus. Older students also are more likely to be enrolled part time, enrolled in an occupational as opposed to an academic program, and seeking occupational certificates as opposed to associate degrees. Older students are also much less likely to be thinking of transferring to 4-year colleges. The fact that many older students are first-time college students means, however, that they may be more motivated because $60 \%$ often seek some types of degree. Calcagno et al. (2007) based their research on Tinto's model of student integration as well as Bean's (1982) student attrition model, both of which call for institutions to foster engagement to aid in retention.

Data from attrition studies generally revealed that students who had good high school records came from higher income families, had parents who went to college, attended full time, received aid, and did not interrupt college were more likely to graduate. Bean's (1982) model of attrition attends to the special problems of older students and recognizes that they are "more negatively affected by environmental factors than they are positively affected by social and academic integration," meaning that they are more likely to drop out (Calcagno et al., 2007, p. 775). Furthermore, older students may not require integration in order to graduate.

Tinto's (1997) and Bean's (1982) models have also been used as the basis for tracking pathways through college, pointing to several key junctures where students are more likely to drop out and setting up a model of which milestones need to be reached in the pathway toward graduation in a certain amount of time in order to remain on target for graduation (Calcagno et al. 2007).

\section{Student Academic Factors}

Henderson, Nunez-Rodriguez, and Casari (2011) reported that $70 \%$ of college-level instructors believed that students are not being adequately prepared in high school to read and comprehend complex materials, $66 \%$ believed students are not taught to think analytically, and 59\% believed that they were not trained to do research. Henderson et al. specifically studied this problem in a community college serving 90\% African American and Hispanic students. Some $80 \%$ of the student body required developmental or remediation classes upon entering the community college. The researchers tested the effectiveness of a research unit in a General Biology course to help community college students overcome research problems. The degree to which students developed information literacy skills was measured by a pretest and posttest structure.

The results reflected that the degree of confidence students had in seeking information increased from $27 \%$ before the course to $74 \%$ after taking the course. The degree of student confidence in navigating the library's resources likewise increased from $17 \%$ to $88 \%$, and the percentage of students who used peerreviewed scientific material in this context of research for this biology course increased to $40 \%$ over the period of the course. Some $86 \%$ recognized the impact of this learning experience on the improvement of their general education skills. Overall, then, although finding that incoming freshmen at a community college were in need of remedial education, Henderson et al. (2011) also found that students were able to develop research skills in the context of a biology course, regardless of demographic or academic backgrounds. As the literacy skills learned in the course influenced student performance favorably in all areas of their lives, Henderson et al. concluded that "colleges can help their students succeed not only in their academic studies but in their workplace and personal lives" (p. 274).

\section{Academic Integration Factors}

A considerable body of research has shown that student academic integration, defined by the time and energy a student gives to educationally purposeful activities, is strongly correlated with graduation rates. More recent research suggested that student engagement may be even more important for minority and 
1st-year college students (Bahr, 2008b; Eagan \& Jaeger, 2009; Fruge \& Ropers-Huilman, 2008; Jacoby, 2006; Kim, 2007; Leigh \& Gill, 2009; Nutting, 2011). Research has indicated that, on average, most African American and Hispanic college students carry more than two risk factors of leaving college, whereas the possession of any one risk factor greatly increases their chance of attrition. This is because minority students are more likely to be independent financially, which means they work, are part-time students, and have dependents. They are also less academically prepared and often require transitional support to enter college.

\section{Strategies for Improving Graduation Rates Based on Retention and Integration Models}

Many of the strategies developed to help with community college retention likely have been modeled on and, then, modified from retention strategies developed for 4-year college students (Escobedo, 2007; Gonzalez, 2011a; Mackay, 2009; Smith, 2010; Stimpfel, 2008; Veenstra, 2009; Woolsey \& Shepler, 2007). Veenstra (2009) reported that retention became an issue in 4-year colleges when administrators began to notice that freshmen years suffered excessive departures of students. This forced institutions to create student support activities based on a student's precollege characteristics, ranging from academic to social and socioeconomic factors, to help improve freshmen-year retention. The urgency of retention efforts was redoubled when cost-benefit studies indicated how much it cost a college to lose a student to attrition compared to what was gained by retention. These have taken the form of orientation, freshmen experience programs, transition programming, mentoring, advising, learning communities, and other engagement activities, all designed for freshmen (Veenstra, 2009). Most of these programs have been influenced by Tinto's (1987) model relative to the academic and social side of the student as they measure such precollege characteristics as high school academic performance, quantitative skills, confidence in quantitative skills, study habits, commitment to career, commitment to college the student is attending, financial needs not met, family support, and social engagement. Veenstra proposed a model for an optimal freshman retention program based on these factors that may well serve as a model for community college retention strategies as well.

One strategy developed by some community colleges to improve student engagement and, therefore, retention rate, was to put students into learning communities. Learning communities include groups of students with similar needs placed in clusters who take the same courses in order to develop academic and social integration. Learning communities also create a seamless learning environment by coordinating different courses in a curriculum so that students are better able to see how their studies connect.

Smith (2010) examined the effectiveness of learning communities at 13 different community colleges for students who speak English as a second language. Smith presented a case study that compared the retention rates of students who were placed in a learning community with one developmental course and students who were only placed in a stand-alone developmental course. The results indicated that participation in the learning community improved student self-perception as students and their perception of the value of their education and revealed that they felt more supported by the institution.

\section{METHODOLOGY}

The purpose of this study is to explore the relationship between selected background, financial, and academic variables and students' timely graduation from a community college campus in central Florida that was the focus of this study. The literature review showed that most research on retention had been done at 4-year colleges. Therefore, this research contributed to the body of knowledge on retention strategies at the community college level (Romano \& Dellow, 2009; Sbrega, 2012). The literature review highlighted the fact that community college students tend to have different characteristics than 4-year college students because they are likely to be nontraditional students who typically are older, are working, have children, and have a busy schedule that prevents them from integrating in college activities. Lack of preparedness for college and for interaction with community college officials and lack of adequate college support are challenges confronting nontraditional students that need to be addressed with situational reforms. 


\section{Participants}

The population for this study was first-time, full-time students who graduated between 2011 and 2013 at one community college campus in central Florida. From this population, a sample of 100 students was selected based on the anticipated survey results. The primary factor for selecting 2011 to 2013 was an anticipated higher response rate by participants in the study based on their recent experiences with the community college. The basis for focusing on first-time, full-time students who graduated in 2011 to 2013, rather than on all students who graduated during that time period, was to explore and understand which variables contributed to their timely graduation.

A participation letter was emailed to the participants inviting to take the survey and explaining the procedures (see Appendix A). The letter explained the purpose and importance of the survey, that participation was voluntary, that individual students' names were not attached to any responses, and the intended use of the results.

\section{Instruments}

A survey questionnaire was used to collect data for this research. A questionnaire is "a form used in survey designs that participants in a study complete and return to the researcher" (Creswell, 2005, p. 402). There are several types of questionnaires used in quantitative survey research; however, the type that was used in this research study was an electronic questionnaire.

The survey questionnaire method used the following scales: nominal, ordinal, and ratio. According to Babbie (2004), nominal measures are for variables that are mutually exclusive and exhaustive, ordinal scales are a comparative measurement that ranks variables by stating that one is more than another, and ratio measures are levels of measurement that describe variables that have the characteristics of all of the aforementioned scales of measurement and have a true zero point.

The researchers developed a questionnaire that was used to collect data on the participants' perceptions and experiences of the factors that contributed to their timely graduation. The questionnaire used a 5-point Likert-like scale, which, according to Creswell (2003), is the most frequently used form for studies such as this. Likewise, "Yes," "No," and open response questions were also used in the questionnaire. The study measured students' perceptions and experiences that contributed to their timely graduation. Development of the survey questions was guided by the study's conceptual framework, Tinto's (1975) student integration model. The validity of the Tinto (1975) model has been tested in various institutional settings.

\section{Procedures}

The electronic survey developed by the researchers consisted of two parts: The first part included a welcome screen and informed consent form, and the second part consisted of the survey questionnaire. The following are the contents of the survey:

1. Welcome screen and informed consent form. The survey began with a welcome screen stating the basic purpose of the survey followed by the informed consent. Survey participants had to agree to the conditions stated in the informed consent before they could continue to complete the survey. The informed consent form guaranteed participants confidentiality and that they would be able to exit the survey at any time.

2. Survey questionnaire. The survey questionnaire (see Appendix B) conformed to Tinto's (1975) conceptual framework. It consisted of background, financial, academic, and institutional integration variables. Background variables included those related to gender, race, age, year of graduation, and the highest level of formal education completed by parents. Financial variables included those related to financial support, financial aid, and employment during college. Academic variables included those related to high school preparation, campus activities, and developmental courses. Last, institutional integration variables included those 
related to effective teaching, faculty interaction, academic feedback, and class registration availability.

After the survey was created, the next step was to build a student graduate participant database that included 2011 to 2013. The researcher obtained permission from the college's registrar who was responsible for certifying graduation credentials to access the data bank that contained the list of the firsttime, full time students who had graduated in 2011, 2012, and 2013, along with their email addresses.

The survey questionnaire was administered online using SurveyMonkey web-service software accessed at SurveyMonkey.com. This self-service website allowed the researcher to upload and manage participant contact information and survey administration tools, including those for tracking survey responses and sending personalized electronic messages. The SurveyMonkey.com website stores the list of participants' emails as well as responses in a password-protected location, which was accessible only to the researcher.

The researchers uploaded the e-mail addresses list of the first-time, full time students who graduated in 2011, 2012, and 2013 into the SurveyMonkey.com website where it was integrated with the survey administration services component. The following steps were conducted through the automated SurveyMonkey process:

1. Participants received an email invitation to participate in the study and take the survey. A link to the survey website was included in the email.

2. The survey contained the required consent form.

3. Participants were invited to take the survey upon approval of the consent form.

4. An email reminder was sent a week later to those who did not respond.

5. Another email reminder was sent a week later to those who did not respond.

All data collected in this study were analyzed using Statistical Package for the Social Sciences (SPSS), Version 22.0. The results of the study were analyzed, conclusions drawn, and recommendations reported.

\section{Limitations}

Obtaining a higher response rate was a limitation for this study. Additionally, because the survey was confined to one campus, to one group of students (i.e., first-time, full-time students), and to a selected time period (2011 to 2013), the results may not be generalizable to the entire community college.

\section{Results}

The purpose of this study is to explore the factors that influence students' timely graduation at the community college. The researchers identified background, financial, and academic variables and explored the relationship between those variables and students' timely graduation at the community college campus that was the focus of this study. Data for this research were collected using a survey questionnaire that encompassed the variables identified above. The ultimate aim of the study was to provide insight into the high rate of students who did not graduate on time and the strategies that may be most effective in reducing that rate. In order to provide focus for this study, the following research question was established:

1. What is the relationship between background, financial, and academic variables related to first-time, full-time students who graduated between 2011 and 2013 from the community college campus and the students' timely graduation; specifically, is there a statistically significant correlation between the variables and graduation, and what is the strength of the correlation?

Tinto's (1975) student integration model guided the development of the survey questionnaire items used for the study. The survey included 16 items encompassing student background variables, financial variables, and academic variables. 
There were six items related to background variables, including items addressing age, gender, and race and ethnicity. There were four items related to financial variables, including items addressing financial support, financial aid, and employment during college.

There were seven academic variables, including those related to high school preparation, campus activities, and developmental courses.

The survey questionnaire was administered online using SurveyMonkey web-service software into which the email addresses of the individuals composing the sample group were entered and integrated with the web-based survey administration services component. Participants received an email invitation to participate in the study and take the survey. A link to the survey website was included in the email. The survey contained a participation letter. Participants were invited to take the survey upon approval of a consent form.

A total of 3,884 surveys were disseminated to prospective survey participants using SurveyMonkey. One week following initial dissemination, an email reminder was sent via SurveyMonkey to the individuals who had not responded. Two weeks later, another email reminder was sent to the individuals who had not responded to the second email.

The total number of survey respondents was 91 , generating a $2.4 \%$ response rate. Although the number of emails was high, not all were active as many students moved or stopped using and receiving emails from the college; therefore, the survey invitations never reached them.

Statistical analysis of the survey data was completed using SPSS, Version 22.0. Selected survey items were coded and are referenced in the survey result tables.

\section{Demographics of Survey Participants}

The demographics included age, gender, and race and ethnicity. Of 91 survey respondents, 35 were male $(38.5 \%)$, and 56 were female $(61.5 \%)$. The mean age of respondents was 24.16 years with a standard deviation of 6.8 .

The race and ethnicity of the survey respondents included 47 White $(51.6 \%), 21$ Hispanic $(23.1 \%)$, 11 African American (12.1\%), nine multiple ethnicity or other (9.9\%), and three Asian Indian (3.3\%). The demographics of the sample participants were consistent with those individuals attending community colleges in the United States.

\section{Correlation Analysis Results}

Correlation analysis was used to describe the strength and direction of the linear relationship between two or more variables.

Table 1 indicates a strong, positive relationship between the father's education and the mother's education $(r=.55)$, which indicated that there was a relationship between parents' education and students' timely graduation. Academically prepared for college was positively correlated with high school preparation for college $(r=.44)$ and self-motivated to do well in school $(r=.36)$, which indicated that there was a relationship between high school preparation and graduating on time from college. 
TABLE 1

\section{CORRELATION BETWEEN FATHER'S EDUCATION, MOTHER'S EDUCATION, ACADEMICALLY PREPARED FOR COLLEGE, SELF-MOTIVATION, AND HIGH SCHOOL PREPARATION FOR COLLEGE $(\mathbf{N}=91)$}

\begin{tabular}{|c|c|c|c|c|c|}
\hline Variable & $\mathrm{A}$ & $\mathrm{B}$ & $\mathrm{C}$ & $\mathrm{D}$ & $\mathrm{E}$ \\
\hline $\mathrm{A}$ & & & & & \\
\hline Pearson correlation & 1.000 & $0.556 * *$ & -0.203 & 0.150 & $-0.247^{*}$ \\
\hline Sig. (2-tailed) & -- & .000 & .054 & .155 & 0.18 \\
\hline thes & $0.556^{* *}$ & 1.000 & $-0.239^{*}$ & -0.025 & $-0.250 *$ \\
\hline $\begin{array}{l}\text { Pearson correlation } \\
\text { Sig. (2-tailed) }\end{array}$ & .000 & -- & 0.23 & .812 & .017 \\
\hline $\mathrm{C}$ & -0.203 & $-0.239 *$ & 1.000 & $0.368 * *$ & $0.441 * *$ \\
\hline $\begin{array}{l}\text { Pearson correlation } \\
\text { Sig. (2-tailed) }\end{array}$ & .054 & 0.23 & -- & .000 & .000 \\
\hline $\mathrm{D}$ & 0.150 & -0.025 & $0.368 * *$ & 1.000 & 0.125 \\
\hline $\begin{array}{l}\text { Pearson correlation } \\
\text { Sig. (2-tailed) }\end{array}$ & .155 & .812 & .000 & -- & .239 \\
\hline $\mathrm{E}$ & $-0.247 *$ & $-0.250 *$ & $0.441 *$ & 0.125 & 1.000 \\
\hline $\begin{array}{l}\text { Pearson correlation } \\
\text { Sig. (2-tailed) }\end{array}$ & .018 & .017 & .000 & .239 & -- \\
\hline
\end{tabular}

Table 2 indicates a strong, positive relationship between the persistence in college and overall satisfaction in college $(r=.52)$, which indicated that students persisting in college were overall satisfied with their college experiences. Financial aid support was negatively correlated with overall satisfied with college experience $(r=.39)$, which indicated that the need for financial aid made it harder for students to enjoy their college experiences. Working to support family was negatively correlated with persistence in college $(r=-.45)$ and overall satisfied with college experience $(r=-.44)$, which indicated that students did not enjoy their college experiences because they had to work to support their families. 
TABLE 2

CORRELATION BETWEEN NONFINANCIAL SUPPORT, FINANCIAL SUPPORT, WORK TO SUPPORT FAMILY, OVERALL SATISFACTION IN COLLEGE, AND PERSISTENCE IN COLLEGE $(\mathbf{N}=91)$

\begin{tabular}{|c|c|c|c|c|c|}
\hline Variable & A & B & $\mathrm{C}$ & $\mathrm{D}$ & $\mathrm{E}$ \\
\hline \multicolumn{6}{|l|}{ A } \\
\hline Pearson correlation & 1.000 & 0.035 & $0.223 *$ & $-0.393 * *$ & -0.003 \\
\hline Sig. (2-tailed) & -- & .742 & .033 & .000 & .975 \\
\hline \multicolumn{6}{|l|}{ B } \\
\hline Pearson correlation & 0.035 & 1.000 & $-0.234^{*}$ & -0.200 & -0.088 \\
\hline Sig. (2-tailed) & .742 & -- & .026 & .057 & .48 \\
\hline \multicolumn{6}{|l|}{$\mathrm{C}$} \\
\hline Pearson correlation & $0.223 *$ & 0.234 & 1.000 & $-0.440 * *$ & $-0.456^{*}$ \\
\hline Sig. (2-tailed) & .033 & .026 & -- & .000 & .000 \\
\hline \multicolumn{6}{|l|}{ D } \\
\hline Pearson correlation & $-0.393 * *$ & -0.200 & $-0.440 * *$ & 1.000 & $0.524 * *$ \\
\hline Sig. (2-tailed) & .000 & .057 & .000 & -- & .000 \\
\hline \multicolumn{6}{|l|}{$\mathrm{E}$} \\
\hline Pearson correlation & -0.003 & -0.088 & $0.456 * *$ & $0.524 * *$ & 1.000 \\
\hline Sig. (2-tailed) & .975 & .408 & .000 & .000 & -- \\
\hline
\end{tabular}

Table 3 indicates the strength of the correlation coefficients between males and females and the selected variable. From the output given below, the correlation between academically prepared for college, self-motivated to do well in college, and persistence in college was insignificant for males $(r=$ .189 and $r=-.014)$, whereas, for females, there was a strong, positive correlation $(r=.370$ and $r=.390)$. 
TABLE 3

CORRELATION RELATIONSHIP BETWEEN GENDER AND ACADEMICALLY PREPARED FOR COLLEGE, SELF-MOTIVATED TO DO WELL IN COLLEGE, AND PERSISTENCE IN COLLEGE

\begin{tabular}{|c|c|c|c|}
\hline Variable & A & $\mathrm{B}$ & $\mathrm{C}$ \\
\hline & \multicolumn{3}{|c|}{ Male } \\
\hline \multicolumn{4}{|l|}{ A } \\
\hline Pearson correlation & 1.000 & 0.189 & 0.014 \\
\hline Sig. (2-tailed) & -- & .276 & .935 \\
\hline B & 0.189 & 1.000 & 0.213 \\
\hline Pearson correlation & .276 & -- & .218 \\
\hline \multicolumn{4}{|l|}{ Sig. (2-tailed) } \\
\hline \multicolumn{4}{|l|}{$\mathrm{C}$} \\
\hline Pearson correlation & -0.014 & 0.213 & 1.000 \\
\hline \multirow[t]{2}{*}{ Sig. (2-tailed) } & .935 & .218 & -- \\
\hline & \multicolumn{3}{|c|}{ Female } \\
\hline \multicolumn{4}{|l|}{ A } \\
\hline Pearson correlation & 1.000 & $0.374 * *$ & $0.393 * *$ \\
\hline Sig. (2-tailed) & -- & .005 & .003 \\
\hline \multicolumn{4}{|l|}{ B } \\
\hline Pearson correlation & $0.374 * *$ & 1.000 & $0.524 * *$ \\
\hline Sig. (2-tailed) & .005 & -- & .000 \\
\hline \multicolumn{4}{|l|}{$\mathrm{C}$} \\
\hline Pearson correlation & $0.393 * *$ & $0.542 * *$ & 1.000 \\
\hline Sig. (2-tailed) & .003 & .000 & -- \\
\hline
\end{tabular}

Note. $\mathrm{A}=$ academically prepared for college; $\mathrm{B}=$ Self-motivated to do well in college; $\mathrm{C}=$ persistence in college; $N$ for males $=35 ; N$ for females $=56$.

${ }^{* *}$ correlation is significant at the .01 level (2-tailed).

\section{Multiple Regressions Analysis Results}

Multiple regressions were used to show how well a set of variables were able to predict a particular outcome. For the purpose of this research, standard multiple regression was used in which independent (predictor) variables were entered into the equation simultaneously (Stevens, 1996).

Table 4 shows how much of the variance $\left(R^{2}\right)$ in the dependent variable (overall college satisfaction) was explained by the independent variables (persistence in college, no financial aid support, financial aid support, race, campus activities, gender, mother's education, self-motivated to do well in school, prepared for college, working to support family, and father's education), which was .484. Expressed as a percentage, this means that the model explained $48.4 \%$ of the variance in overall college satisfaction. Moreover, the model reached statistical significance $(\mathrm{Sig}=.000, p<.0005)$. 
TABLE 4

REGRESSION ANALYSIS OF VARIANCE FOR VARIABLES PREDICTING TIMELY GRADUATION

\begin{tabular}{cccccc}
\hline Model & $S S$ & $d f$ & $M S$ & $F$ & Sig. \\
\hline Regression & 35.994 & 11 & 3.272 & 6.724 & $.000^{\mathrm{a}}$ \\
Residual & 38.446 & 79 & 0.487 & & \\
\hline
\end{tabular}

Note. $R^{2}=.484$; dependent variable $=$ overall students' satisfaction in college; ${ }^{\text {a }}$ predictors of timely graduation $=$ persistent in college, no financial aid support, financial aid support, race, gender, campus activities, mother's education, self-motivated to do well in college, academically prepared to do well in college, work to support family, and father's education.

Table 5 indicates the coefficients, specifically, the column Beta, of the variable included in the regression model contributed to the prediction of the dependent variable. The largest beta coefficient was .495 for student persistence in college. This means that student persistence in college made the strongest unique contribution to explaining the dependent variable when the variance explained by all the other variables in the column Beta, of the variable included in the regression model contributed to the prediction of the dependent variable. The largest beta coefficient was .495 for student persistence in college. This means that student persistence in college made the strongest unique contribution to explaining the dependent variable when the variance explained by all the other variables in the regression model was controlled for. The beta value for financial aid support was .400 , and the lower beta values indicated that these variables made less of a contribution.

\section{TABLE 5 \\ REGRESSION COEFFICIENTS OF THE MEASURED INDEPENDENT VARIABLES ON THE DEPENDENT VARIABLE}

\begin{tabular}{cccccc}
\hline \multicolumn{2}{c}{ Unstandardized coefficients } & \multicolumn{3}{c}{ Standardized coefficients } \\
\hline Variable & Beta & Std. error & Beta & $t$ & Sig. \\
\hline $\mathrm{A}$ & .032 & .041 & .087 & 0.785 & .435 \\
$\mathrm{~N}$ & .003 & .037 & .008 & 0.074 & .941 \\
$\mathrm{C}$ & .210 & .178 & .113 & 1.176 & .243 \\
$\mathrm{D}$ & -.039 & .089 & -.040 & -0.434 & .666 \\
$\mathrm{E}$ & -.236 & .055 & -.400 & -4.313 & .000 \\
$\mathrm{~F}$ & -.400 & .194 & -.195 & -2.060 & .043 \\
$\mathrm{G}$ & -.069 & .075 & -.095 & -0.919 & .361 \\
$\mathrm{H}$ & -.080 & .084 & -.100 & -0.959 & .340 \\
$\mathrm{I}$ & -.051 & .089 & -.048 & 0.567 & .572 \\
$\mathrm{~J}$ & -.059 & .147 & -.043 & -0.403 & .688 \\
$\mathrm{~K}$ & .546 & .113 & .495 & 4.824 & .000 \\
\hline
\end{tabular}

Note. dependent variable $=$ overall student satisfaction; $\mathrm{A}=$ father's education; $\mathrm{B}=$ mother's education; $\mathrm{C}=$ gender; $\mathrm{D}=$ race; $\mathrm{E}=$ no financial aid support; $\mathrm{F}=$ financial aid support; $\mathrm{G}=$ work to support family; $\mathrm{H}=$ prepared to do well in college; $\mathrm{I}=$ campus activities; $\mathrm{J}$ = self-motivated to do well in college;

$\mathrm{K}=$ persistent in college.

The research question's results showed that the independent variables (background variable, financial variable, and academic variables) explained $48.4 \%$ of the variance in the dependent variable, overall college experience satisfaction. However, of all the independent variables analyzed, student persistence in college made the largest, unique contribution to the dependent variable (beta $=.495)$.

This chapter presented the results of data analysis. Investigation revealed that student persistence in college was the strongest predictors of students' timely graduation. In addition, faculty interest in student 
achievement, teaching effectiveness, faculty encouragement, and faculty ongoing feedback were also predictors of students 'timely graduation. However, other variables were correlated and demonstrated considerable influence over students' timely graduation.

\section{CONCLUSION}

The findings of this study demonstrated that, although background and academic integration factors exerted a significant influence on community college students' overall satisfaction with college (the proxy for timely graduation), academic integration variables surpassed background variables in their influence. This finding underscored the fallacy of relying on students' socioeconomic backgrounds or high school performances for explaining their success or failure in college. Indeed, these findings placed the responsibility for ensuring that all students had access to rewarding college experiences squarely on community college administration and confirmed the critical importance of faculty in facilitating students' persistence and graduation.

Of the background variables examined in relation to Research Question 1, persistence exerted the strongest influence on students' timely graduation. The powerful impact of academic integration variables reinforced the message that community college administrators cannot dismiss students' lack of persistence on individual factors such as low-SES, first-generation status, poor motivation, or inadequate high school preparation for their difficulties in progressing through college. In fact, attempting to shift the blame to insufficient academic preparation belies the mission of community colleges to educate all students, not to mention the policy mandate to provide students in need of remediation with appropriate academic supports.

A distinctive feature of community colleges is the need to synthesize academic and social integration for students who often do not have time for socializing on campus. Academic integration was selected as the focus of study based on research demonstrating that academic integration is the overriding integration factor in the college experiences of community college students (Deil-Amen, 2011). However, that does not negate the importance of social integration, which can be accomplished classroom arrangements and faculty practices that simultaneously build academic and social integration.

\section{Suggestions for Future Research}

More research needs to be conducted on the factors that influence persistence among part-time students who are at particular risk for dropping out and adult students older than 24 years of age who may differ in their motivations and preferences than their younger counterparts. Academic integration may be particularly important for adult learners, and it is possible that their interactions with faculty who may be their own age or younger and preferences for classroom instruction differ from younger students.

This study examined academic integration factors, but it did not directly explore any specific practices. Future research should explore the nature of practices and techniques associated with excellent classroom instruction, faculty support for achievement, faculty encouragement, and ongoing feedback.

\section{Limitations}

A notable limitation of this study was that the focus was on timely graduation to the exclusion of transfer. Transfer is one aspect of the community college mission that is often neglected. Tinto (1987) recognized that there is a difference between students' persistence and commitment to the institution, which affects graduation. The relationship of persistence to transfer is a good topic for future research. There is definitely a need for more research on how administrators and faculty influence transfer to a baccalaureate program.

\section{Significance}

This study confirmed the significance of the model explaining background factors and the persistence and timely graduation in community college students. This model can be used to guide future research on the college experience and success of community college students. 


\section{Summary}

It is widely accepted that we live in a competitive global society where education beyond high school is requisite for employment success. Community colleges are serving increasingly higher proportions of students in higher education but with disappointing results. Not even one third of first-time, full-time community college students who aspire to earn degrees or certificates accomplish this within 3 years, and less than half accomplish this within 6 years (ACT, 2006). Community colleges serve disproportionate numbers of low-income, minority, and first-generation students, but these students are at particular risk for dropping out before they have earned degrees.

The failure of community colleges to promote the successful degree completion of students runs counter to the mission of public, 2-year colleges to extend opportunities for higher learning to all individuals. Open enrollment policies and low tuition rates expand access to higher education, but they also work to create a student population that is more vulnerable to dropping out than their more advantaged peers. Neglecting the unique needs of these students implies that community college administrators are ailing the population their institutions are intended to serve. Furthermore, community colleges have obligations to multiple stakeholders with increasing demands for results.

This study was designed to examine the factors that influenced first-time, full-time community college students' persistence to timely graduation. Closely aligned with timely graduation, overall satisfaction served as a proxy for timely graduation (Manner et al., 2004). Tinto's (as cited in Deil-Amen, 2011) model of student integration served as the conceptual framework for this study but was adapted to reflect the precedence of academic integration over social integration in shaping the experiences of students attending community college. Using multiple modes of analysis, this study examined the significance of background and academic integration variables.

There were strong correlations between the factors examined. Of all the background factors, persistence in college had the most decisive effect. Academic integration variables have the power to influence students' persistence.

There are many empirically proven practices for enriching the college experiences of community college students and keeping their motivation high for timely graduation. Adopting excellent practices for teaching, learning, and providing students with ongoing support and encouragement is in the best interests of the institutions and the students they serve.

\section{REFERENCES}

American College Testing. (2006). National collegiate and persistence to degree attainment. Iowa City, IA: Author

Aslanian, C. (2001). You're never too old: Excerpts from adult students today. Community College Journal, 71, 56-58.

Astin, A. W. (1993). What matters in college? Four critical years revisited. San Francisco, CA: JosseyBass.

Aud, S., Fox, M., \& KewalRamani, A. (2010). Status and trends in the education of racial and ethnic groups (NCES 2010-015). Washington, DC: U.S. Department of Education, National Center for Education Statistics.

Babbie, E. (2004). The practice of social research (10th ed.). Belmont, CA: Wadsworth.

Bahr, P. R. (2008a). Cooling out in the community college: what is the effect of academic advising on students' chances of success? Research in Higher Education, 49, 704-732. doi:10.1007/s11162008-9100-0

Bahr, P. R. (2008b). Does mathematics remediation work? A comparative analysis of academic attainment among community college students. Research in Higher Education, 49, 420-450. doi:10.1007/s11162-008-9089-4

Bailey, T., \& Alfonso, M. (2005). Paths to persistence: An analysis of research on program effectiveness at community colleges. Lumina Foundation for Education, 6(1), 1-38. 
Bailey, T., Alfonso, M., Calcagno, J. C., Jenkins, D. Kienzl, G., \& Leinbach, T. (2004). Improving student attainment in community colleges: Institutional characteristics and policies. New York, NY: Columbia University, Teachers College, Community College Research Center.

Bean, J. P. (1982). Conceptual models of student attrition: How theory can help the institutional researcher. New Directions for Institutional Research, 1982(36), 17-33.

Bers, T. H., \& Smith, K. E. (1991). Persistence of community college students: The influence of student intent and academic and social integration. Research in Higher Education, 32, 539-556.

Blaauw-Hara, M. (2008). Graduation rates should inform decision-making, not drive it. Community College Week, 20(21), 4.

Bourdieu, P. (1986). The forms of capital. In J. Richardson (Ed.), Handbook of theory and research for the sociology of education (pp. 241-258). New York, NY: Greenwood.

Breier, M. (2010). From financial considerations to poverty: Towards a reconceptualization of the role of finances in higher education student drop out. Higher Education, 60, 657-670. doi:10.1007/s10734-010-9343-5

Calcagno, J. C., Crosta, P., Bailey, T., \& Jenkins, D. (2007). Stepping stones to a degree: The impact of enrollment pathways and milestones on community college student outcomes. Research in Higher Education, 48, 775-803. doi:10.1007/s11162-007-9053-8

Chan, S. F., Chau, A. W. L., \& Chan, K. Y. K. (2012). Financial knowledge and aptitudes: Impacts on college students' financial well-being. College Student Journal, 46, 114-133.

Chapa, J., \& Schink, W. (2006). California community colleges: Help or hindrance to Latinos in the higher education pipeline? New Directions for Community Colleges, 133, 41-52. doi: $10.1002 /$ cc. 226

Cohen, A. M., \& Brawer, F. B. (2009). The American community college. San Francisco, CA: JosseyBass

Complete College America. (2011). Remediation: Higher education's bridge to nowhere. Retrieved from http://www.completecollege.org/docs/CCA-Remediation -final.pdf

Cooper, M. (2010, October). Student support services at community colleges: A strategy for increasing student persistence and attainment. Paper presented at the White House Summit on Community Colleges, Washington, DC.

Craig, A., \& Ward, C. (2007). Retention of community college students: Related student and institutional characteristics. Journal of College Student Retention: Research, Theory, and Practice, 9, 505517. doi:10.2190/CS.9.4.f

Creswell, J. W. (2003). Research design: Qualitative, quantitative, and mixed-methods approaches (2nd ed.). Thousand Oaks, CA: Sage.

Creswell, J. W. (2005). Educational research: Planning, conducting, and evaluating quantitative and qualitative research (2nd ed.). Upper Saddle River, NJ: Pearson Education.

Crisp, G., \& Nora, A. (2010). Hispanic student success: factors influencing the persistence and transfer decisions of Latino community college students enrolled in developmental education. Research into Higher Education, 51, 175-194. doi:10 .1007/s11162-009-x

Deil-Amen, R. (2002). From dreams to degrees: Social processes of opportunity and blocked opportunity in community colleges (Unpublished doctoral dissertation). Northwestern University, Evanston, IL.

Deil-Amen, R. (2011). Socio-academic integrative moments: Rethinking academic and social integration among two-year college students in career-related programs. Journal of Higher Education, 82, 54-91.

Derby, D. (2006). Community college student retention: A comparison of White, Hispanic, and African American students. Thresholds in Education, 32(1), 10-15.

Dervarics, C. (2011). Education department's community college leader makes acceleration strategies part of ambitious agenda. Diverse: Issues in Higher Education, 28(15), 6.

Doyle, W. R. (2006, May). Community college transfers and college graduation: Whose choices matter most? Change, 38, 56-59.

114 Journal of Higher Education Theory and Practice Vol. 19(6) 2019 
Eagan, M. K., \& Jaeger, A. J. (2009). Effects of exposure to part-time faculty on community college transfer. Research in Higher Education, 50, 168-188. doi:10 .1007/s11162-008-9113-8

Escobedo, G. (2007). Retention/persistence intervention model: Improving success across cultures. Journal of Developmental Education, 31, 12-19.

Feldt, R. C., Brokens, A., Bullock, M., Camarotti-Calvalho, A., Collingwood, M., Eilers, . . Nurre, E. (2010). Factorial structure of the career decision scale: Incremental validity of the five-factor domains. Measurement and Evaluation in Counseling and Development, 42, 235-245.

Fisher, M. J. (2007). Study finds California community colleges struggling with high attrition, low graduation rates. Community College Week, 19(9), 3-10.

Friedl, J., Pittenger, D. J., \& Sherman, M. (2012). Grading standards and student performance in community college and university courses. College Student Journal, 46, 526-532.

Fruge, C. W., \& Ropers-Huilman, R. (2008). Epistemological congruency in community college classrooms: Effects of epistemological beliefs on students' experiences. College Teaching, 56, 121-128. doi:10.3200/CTCH.56.2.121-128

Giegerich, S. (2006). Barrier busters: Two-year institutions help students achieve their dreams. Retrieved from http://www.luminafoundation.org/publications/focus_archives/winter_2006/ twoyearinstitutions.html

Goble, L.J., Rosenbaum, J. E., \& Stephan, J. L. (2008). Do institutional attributes predict individual's degree success at two-year colleges? New Directions for Community Colleges, 144, 63-74. doi: $10.1002 /$ cc. 346

Gonzalez, J. (2009, November 16). Connecting with part-timers is key challenge for community colleges, survey finds. The Chronicle of Higher Education, p. A19.

Gonzalez, J. (2011a, September 4). Antipoverty group works with community colleges to graduate more students. The Chronicle of Higher Education. Retrieved from http://www.chronicle.com/article/Antipoverty-Group-Works-With/128874

Gonzalez, J. (2011b, June 12). Go to community college, earn a bachelor's degree: Florida likes that combination. The Chronicle of Higher Education, p. A1.

Greene, T. G., Marti, C. N., \& McClenney, K. (2008). The effort-outcome gap: Differences for African American and Hispanic community college students in student engagement and academic achievement. Journal of Higher Education, 79, 513-541.

Grubb, N. (2001). Getting into the world: Guidance and counseling in community college. New York, NY: Columbia University, Teachers College, Community College Research Center. Retrieved from http://www.ccrc.tc.columbia.edu

Hagedorn, L. S., Chi, W., Cepeda, R. M., \& McLain, M. (2007). An investigation of critical mass: The role of Latino representation in the success of urban community college students. Research in Higher Education, 48, 73-92. doi:10.1007/s11162-006-9024-5

Henderson, F., Nunez-Rodriguez, N., \& Casari, W. (2011). Enhancing research skills and information literacy in community college science students. The American Biology Teacher, 73, 270-276. doi:10.1525/abt.2011.73.5.5

Horn, L., \& Nevill, S. (2006). Profile of undergraduates in U.S. postsecondary education institutions: 2003-04 with a special analysis of community college students (NCES 2006184). Washington, DC: U.S. Department of Education, National Center for Education Statistics.

Jacoby, D. (2006). Effects of part-time faculty employment on community college graduation rates. Journal of Higher Education, 77, 1081-1105.

Kidwell, B., \& Turrisi, R. (2004). An examination of college student money management tendencies. Journal of Economic Psychology, 25, 601-616.

Kim, J. H. (2007). Evaluation of the work-based learning courses in the manufacturing technology program in a community college. College Student Journal, 45, 451-462.

Klimstra, T. A., Luyckx, K., Hale, W. W., Goossens, L., \& Meeus, W. H. J. (2010). Longitudinal associations between personality profile stability and adjustment in college students: 
Distinguishing among overall stability, distinctive stability, and within-time normativeness. Journal of Personality, 78, 1163-1186. doi:10.1111/j .1467.2010.00646.x

Kurlaender, M. (2006). Choosing community colleges: Factors affecting Latino college choice. New Directions for Community Colleges, 133, 7-18. doi:10.1002/cc.223

Leigh, D. E., \& Gill, A. M. (2009). How well do community colleges respond to the occupational training needs of local communities? Evidence from California. New Directions for Community Colleges, 146, 95-104. doi:10.1002/cc.370

Lundberg, C. A. (2010). Institutional commitment to diversity, college involvement, and faculty relationships as predictors of learning for students of color. The Journal of the Professoriate, 3 , 50-77.

Mackay, A. (2009). Arizona universities, community colleges join forces to boost graduation rates. Community College Week, 22(3), 10.

Malcom, L. E. (2010). Charting the pathways to STEM for Latina/o students: The role of community colleges. New Directions for Institutional Research, 148, 29-41. doi: 10.1002/ir.359

Mannan, M. A. (2007). Student attrition and academic and social integration: Application of Tinto's model at the University of Papua, New Guinea. Higher Education, 53, 147-165. doi:10.1007/s10734-005-2496-y

Manner, D., Seaman J. W., \& Young, D. M. (2004). Bayesian methods for regression using surrogate variables. Biometrical Journal, 46, 750-759.

Marti, C. N. (2008). Dimensions of student engagement in American community colleges: Using the Community College Student Report in research and practice. Community College Journal of Research and Practice, 33(1), 1-24.

Martinez, M., \& Fernandez, E. (2004). Latinos at community college. New Directions for Student Services, 105, 51-65.

Melguizo, T., Kienzl, G. S., \& Alfonso, M. (2011). Comparing the educational attainment of community college transfer students and 4-year college rising juniors using propensity score matching methods. Journal of Higher Education, 82, 265-293.

National Center for Education Statistics. (2004). Statistical analysis: A report. Educational achievement and Black-White inequality. Washington, DC: U.S. Department of Education, Office of Educational Research and Improvement.

Nora, A. (1990). Testing qualitative indicators of precollege factors in Tinto's attrition model: A community college student population. Review of Higher Education, 13, 337-355

Nutting, A. W. (2011). Community college transfer students' probabilities of baccalaureate receipt as a function of their prevalence in 4-year colleges and departments. Education Economics, 19, 65-87. doi:1080/09645290902500560

O’Connor, N. (2009). Hispanic origin, socio-economic status, and community college enrollment. Journal of Higher Education, 80, 121-147.

O’Gara, L., Karp, M. M., \& Hughes, K. L. (2009). An exploratory study of student perspectives. Community College News, 36, 1-19.

Pascarella, E. T., \& Terenzini, P. T. (2005). How college affects students: A third decade of research. San Francisco, CA: Jossey-Bass.

Patel, R, \& Richburg-Hayes, L. (2011). Performance-based scholarships: Emerging findings from a national demonstration. New York, NY: Manpower Demonstration Research Corporation. Retrieved from http://www.mdrc.org/sites/default/files/policybrief_41.pdf

Perrakis, A. I. (2008). Factors promoting academic success among African American and White male community college students. New Directions for Community Colleges, 142, 15-24. doi:10.1002/cc.321

Pintrich, P. R., \& Schunk, D. H. (2002). Motivation in education: Theory, research, and application (2nd ed.). Upper Saddle River, NJ: Pearson Education.

Ramage, T. (2011). What is next? Futuristic thinking for community colleges. New Directions for Community Colleges, 154, 107-115. doi:10.1002/cc.451

116 Journal of Higher Education Theory and Practice Vol. 19(6) 2019 
Roman, M. (2007). Community college admission and student retention. Journal of College Admission, $194,18-25$.

Romano, R. M., \& Dellow, D. A. (2009). Technological change, globalization, and the community college. New Directions for Community Colleges, 146, 11-20. doi:10 .1002/cc.362

Sbrega, J. J. (2012). Grad rates don't tell full story of community college performance. New England Journal of Higher Education, 5, 1-2.

Scoggin, D., \& Styron, R. A. (2006). Factors associated with student withdrawal from community college. Retrieved from ERIC database. (EJ846010)

Smith, R. A. (2010). Feeling supported: Curricular learning for basic skills courses and students who speak English as a second language. Community College Review, 37, 1-28.

Sparkman, L. A., Maulding, W. S., \& Roberts, J. G. (2006). Non-cognitive predictors of student success in college. College Student Journal, 62, 642-656.

Stevens, J. (1996). Applied multivariate statistics for social sciences (3rd ed.). Mahwah, NJ: Lawrence Erlbaum.

Stimpfel, S. (2008). REEEO: giving community college students a leg up. Phi Kappa Phi Forum, 88, 1217.

Strauss, L., \& Volkwein, F. J. (2004). Predictors of student commitment at two-year and 4-year institutions. Journal of Higher Education, 75, 50-55.

Tinto, V. (1975). Dropout from higher education: A theoretical synthesis of recent research. Review of Educational Research, 45, 89-125.

Tinto, V. (1985). Dropping out and other forms of withdrawal from college. In L. Noel, R. Levitz, \& D. Saluri (Eds.), Increasing students retention: Effective programs and practices for reducing the dropout rate (pp. 28-43). San Francisco, CA: Jossey-Bass.

Tinto, V. (1987). Leaving college: Rethinking the causes and cures of student attrition. Chicago, IL: University of Chicago Press.

Tinto, V. (1995). Leaving college. Rethinking the causes and cures of student attrition (2nd ed.). Chicago, IL: University of Chicago Press.

Tinto, V. (1997). Universities as learning organizations. About Campus, 1(6), 2-5.

Upcraft, M. L., Gardner, J. N., \& Barefoot, B. (2005). Challenging and supporting the first-year student. San Francisco, CA: Jossey-Bass.

U.S. Census Bureau. (2009). American community survey: Ranking tables for education, 2006 and 2007. Retrieved from http://www.factfinder.census.gov

Valencia College (2012). Strategic plan, 2005-2009. Retrieved from http://www.valenciacollege.edu/IR/Reporting/external/IPEDS.cf

Veenstra, C. P. (2009). A strategy for improving freshman college retention. The Journal for Quality and Participation, 19(1), 19-25.

Woolsey, S. A., \& Shepler, D. K. (2007). Understanding the early integration experiences of first generation college students. College Student Journal, 43, 700-715 